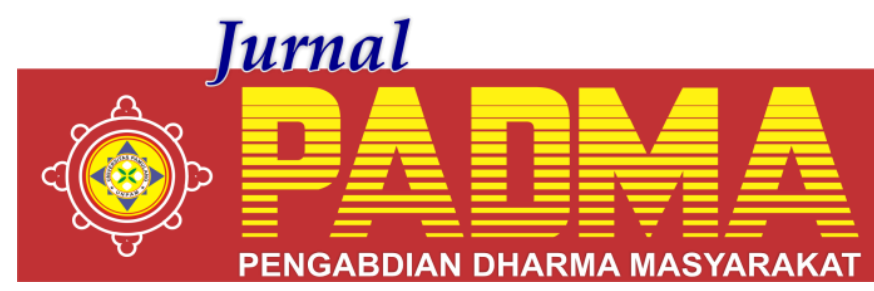

VOLUME 1, NOMOR 3, JULI 2021

\title{
MENINGKATKAN KESADARAN MASYARAKAT TENTANG PENTINGNYA VAKSINASI DI MASJID AL - IKHLAS, JAKARTA BARAT
}

\author{
${ }^{1 * I s k a k, ~}{ }^{2}$ Muhammad Zuaim Rusydi, ${ }^{3}$ Roni Hutauruk, ${ }^{4}$ Shoful Chakim, \\ 5Wildan Ramdani Ahmad \\ Universitas Pamulang, Tangerang Selatan, Banten, Indonesia \\ *iskak240498@gmail.com
}

\begin{abstract}
Abstrak
Vaksinasi adalah proses pemberian vaksin melalui disuntikkan maupun diteteskan ke dalam mulut untuk meningkatkan produksi antibodi guna menangkal penyakit tertentu. Dalam melaksanakan kegiatan PKM digunakan beberapa metode, yaitu: Metode Presentasi. Metode presentasi dipilih untuk memberikan penjelasan tentang vaksinasi. Metode Tanya Jawab. Metode tanya jawab sangat penting bagi para peserta. Metode ini memungkinkan jamaah masjid Al-Ikhlas mendapatkan wawasan tentang pentingnya vaksinasi COVID-19 di masa pandemi saat ini;. Sharing Session Tentang vaksinasi COVID-19. Sharing session ini diberikan kepada para peserta dalam memberikan masukan dan bimbingan untuk materi yang diperoleh. hasil pengabdian ini menunjukkan bahwa jamaah masjid Al-Ikhlas sangat antusias mengikuti dari awal sampai akhir.
\end{abstract}

Kata Kunci: Pengabdian Kepada Masyarakat, Covid-19, Vaksinasi, Masjid Al-Ikhlas

\section{Abstract}

Vaccination is the process of giving vaccines by injection or dripping into the mouth to increase the production of antibodies to ward off certain diseases. In carrying out PKM activities, several methods are used, namely: Presentation Method. The presentation method was chosen to provide an explanation of vaccination. Question and answer method. The question and answer method is very important for the participants. This method allows the congregation of Al-Ikhlas mosque to gain insight into the importance of COVID-19 vaccination during the current pandemic; Sharing Session About COVID-19 vaccination. This sharing session is given to the participants in providing input and guidance for the material obtained. the results of this dedication show that the congregation of the Al-Ikhlas mosque is very enthusiastic to follow from beginning to end.

Keywords: Community Service, Covid-19, Vaccination, Al-Ikhlas Mosque

\section{PENDAHULUAN}

Untuk menangani pandemi COVID-19, pemerintah membuat berbagai kebijakan guna melindungi masyarakat dari penularan dan dampak COVID-19 mulai dari pembatasan sosial berskala besar termasuk pembatasan sekolah, tempat kerja, tempat peribadatan, tempat umum dan transportasi, pemberian bantuan sosial, pemberian insentif bagi tenaga kesehatan, kebijakan masker untuk semua dan kebijakan penerapan protokol kesehatan di berbagai tempat yang terus digaungkan selagi menanti vaksin.

Pemerintah Indonesia dan juga negara negara di dunia tengah berupaya mengembangkan dan menghadirkan Vaksin COVID-19 serta merencanakan pelaksanaan imunisasi untuk warganya. Vaksin tidak hanya melindungi individu namun juga memberikan perlindungan bagi orang orang yang tidak dapat diimunisasi' contohmya pada usia tertentu maupun orang dengan penyakit tertentu. Vaksin tidak menimbulkan penyakit. Vaksin yang sudah dipakai di masyarakat sudah dijamin keamanannya dan umumnya tidak menimbulkan reaksi simpang (efek samping) yang berat.

Vaksinasi periode pertama telah berlangsung pada Januari 2021 yang diberikan kepada kelompok prioritas, seperti tenaga kesehatan dan petugas publlik. Sementara sisanya akan dilakukan dalam vaksinasi periode kedua yang berlangsung 
selama 11 bulan yakni dari April 2021 hingga Maret 2022.

Adapun sesuai dengan standar Badan Kesehatan Dunia (WHO), setiap penduduk akan mengikuti dua kali penyuntikan atau membutuhkan dua dosis vaksin. Ada tujuh jenis vaksin COVID-19 yang dapat digunakan dalam proses vaksinasi di Indonesia. Ketujuh vaksin tersebut diproduksi oleh Bio Farma, Astra Zaneca, Shinopharm, Moderna, Novavax Inc, Pfizer Inc and BioNtech dan Sinovac Biotech.

Survei terbaru yang dilakukan oleh Saiful Mujani Research and Consulting menunjukkan hanya sekitar 37 persen warga yang "secara tegas" mau divaksinasi COVID19 jika sudah tersedia. 17 persen warga mengatakan tidak akan divaksinasi, bahkan 28 persen warga menyatakan tidak takut tertular COVID-19.

Sebagian besar mengutarakan kemungkinan efek samping dari vaksin ini menjadi faktor kekhawatiran utama, selain juga kurangnya tingkat kepercayaan terhadap pemerintah mengenai keamanan dan efikasinya. Mengingat bahwa vaksin ini masih tergolong sangat baru dan kekhawatiran akan politisasi yang timbul selama proses pembuatan vaksin ini juga meningkatkan keraguan masyarakat. Berbagai mitos dan hoaks yang beredar mengenai vaksin COVID-19 menjadi salah satu faktor yang mendorong keraguan masyarakat untuk menjalani vaksinasi.

Berdasarkan latar belakang tersebut, kami Tim Program Pengabdian Masyarakat (PKM) Universitas Pamulang (UNPAM) yang berjumlah 5 orang mahasiswa terpanggi untuk ikut serta membantu memecahkan persoalan yang dihadapi oleh Organisasi Masyarakat tersebut dengan judul PKM : "Meningkatkan Kesadaran Masyarakat Tentang Pentingnya Vaksinasi di Masjid Al-Ikhlas Jakarta Barat."

Berdasarkan analisis situasi yang telah dipaparkan. Maka rumusan masalah pada PKM ini adalah:

1. Bagaimana memberikan pemahaman mengenai pentingnya vaksinasi COVID-19 di masa pandemi saat ini?

2. Bagaimana memberikan pemahaman wawasan kepada jamaah masjid Al-Ikhlas mengenai manfaat dan dampak positif yang didapat dari vaksinisasi COVID-19?
Tujuan umum dari kegiatan pengabdian kepada masyarakat ini adalah membantu jamaah Masjid Al-Ikhlas Jakarta Barat dalam memahami manfaat dan pentingnya vaksinasi Covid-19, Secara khusus tujuan kegiatan pengabdian kepada masyarakat ini adalah:

1. Memberikan pemahaman tentang pentingnya vaksinasi COVID-19 di masa pandemi saat ini.

2. Memberikan pemahaman wawasan kepada jamaah masjid Al-Ikhlas bagaimana manfaat dan dampak positif dari vaksinisasi COVID-19.

Kegiatan pengabdian masyarakat ini diharapkan dapat memberikan manfaat baik untuk para peserta pelatihan penulisan kegiatan dan surat menyurat maupun bagi para mahasiswa manajemen.

1. Manfaat bagi para peserta pelatihan, kegiatan ini diharapkan dapat menambah pengetahuan dan wawasan mengenai pentingnya vaksinasi Covid-19 di masa pandemi saat ini.

2. Manfaat bagi mahasiswa, kegiatan ini diharapkan dapat menjadi tempat untuk mengamalkan ilmu sebagai wujud peran serta secara nyata pengabdian diri kepada masyarakat.

Ketercapaian target luaran dari kegiatan pengabdian masyarakat dengan kelompok sasaran Jamaah Masjid Al-Ikhlas Cengkareng, Jakarta Barat yang kami lakukan dapat dilihat dari tiga hal. Pertama, ketercapaian tujuan kegiatan sesuai dengan tujuan yang ada pada rencana yang telah disusun di dalam proposal. Kedua, terpublikasikanya aktifitas kegiatan pengabdian kepada masyarakat yang dilakukan oleh tim pengabdi kepada jamaah masjid Al-Ikhlas Cengkareng, Jakarta Barat. Sehingga mampu menjadi penggerak rekan mahasiswa lainya untuk melakukan hilirisasi ilmu di kampus kemasyarakat. Ketiga, luaran yang akan dihasilkan oleh PKM ini berupa Jurnal dengan Judul "Meningkatkan Kesadaran Masyarakat Tentang Pentingnya Vaksinasi di Masjid Al-Ikhlas Jakarta Barat".

\section{METODE}

Metode kegiatan yang dilakukan dalam rangka menyukseskan kegiatan pengabdian ini, yaitu: 
1. Peralatan yang dibutuhkan untuk melaksanan kegiatan ini

Pada tahapan ini pelaksana memulai dengan melakukan koordinasi dengan instansi terkait.

2. Penentuan Lokasi

Pada tahap ini dilakukan kunjungan ke lokasi untuk menentukan tempat (lokasi). Dalam memilih lokasi, kami mempertimbangkan dengan jarak yang kami tempuh dari Universitas ke lokasi pengabdian.

3. Perancangan kebutuhan

Adapun tahapan yang dilakukan dalam perancangan kebutuhan secara berurutan adalah sebagai berikut:

a) Perancangan materi tentang pentingnya vaksinasi COVID-19 di masa pandemi saat ini.

b) Perancangan materi tentang manfaat dan dampak positif dari vaksinasi COVID-19.

c) Perancangan alat. Menyiapkan proyektor.

Metode pendekatan yang digunakan dalam kegiatan ini adalah :

a) Persentasi

b) Tanya Jawab

c) Diskusi / sharing

Dalam upaya mencari solusi atas permasalahan yang dihadapi oleh peserta maka kami menawarkan target solusi dalam penyelesaian sesuai dengan target yang sudah kami siapkan dan kami sepakati dengan pihak mitra. Adapun solusi tersebut akan kami laporkan dalam bentuk luaran kegiatan PKM yang terdiri dari beberapa tahapan.

1. Luaran PKM terkait bagaimana pentingnya vakasinasi COVID-19 di masa pandemi saat ini.

2. Luaran PKM terkait bagaimana manfaat dan dampak positif dari vaksinasi COVID19.

3. Dilaksanakannya penyuluhan mengenai bahaya covid dan juga amannya vaksin Covid yang sudah disediakan oleh Pemerintah.

\section{HASIL DAN PEMBAHASAN}

Vaksinasi adalah proses pemberian vaksin melalui disuntikkan maupun diteteskan ke dalam mulut untuk meningkatkan produksi antibodi guna menangkal penyakit tertentu.

Vaksin merupakan salah satu cara terpenting dan tepat guna untuk mencegah penyakit dan menjaga kondisi tubuh. Vaksin, yang juga sering disebut imunisasi, mengambil keuntungan dari fungsi unik yang dimiliki tubuh dalam mempelajari dan melawan kuman-kuman penyebab penyakit. Vaksin membantu menciptakan kekebalan tubuh untuk melindungi Anda dari infeksi tanpa mengakibatkan efek samping yang membahayakan.

Dengan vaksinasi Covid-19 bisa melindungi tubuh dengan menciptakan respons antibodi di tubuh tanpa harus sakit karena virus corona. Vaksin COVID-19 mampu mencegah seseorang terkena virus corona. Atau, apabila sudah tertular COVID19 , vaksin dapat mencegah tubuh dari sakit parah atau potensi hadirnya komplikasi serius.

Dengan mendapatkan vaksin, maka dapat membantu melindungi orang-orang di sekitar dari virus corona. Terutama orangorang yang berisiko tinggi terkena penyakit parah akibat COVID-19. Menurut penelitian yang dilakukan para ahli, beberapa fakta yang harus diketahui tentang vaksinasi COVID-19 sebagai berikut.

1. Vaksin COVID-19 Tidak Membuat Seseorang Terjangkit COVID-19

Vaksin COVID-19 yang dikembangkan saat ini tidak mengandung virus hidup yang menyebabkan COVID19. Artinya, vaksin COVID-19 tidak membuat terinfeksi COVID-19.

Ada beberapa jenis vaksin yang sedang dikembangkan. Semuanya mengandung zat yang dapat meningkatkan sistem kekebalan yang membuat tubuh mengenali dan melawan virus yang menyebabkan virus corona. Terkadang, proses ini menimbulkan gejala seperti demam ringan. Gejala ini normal dan sebagai tanda bahwa tubuh sedang membangun perlindungan terhadap virus penyebab COVID-19.

2. Setelah Mendapatkan Vaksin COVID-19 tidak akan membuat Positif COVID-19 pada Tes Virus

Baik vaksin yang diizinkan dan direkomendasikan baru-baru ini maupun vaksin COVID-19 lain yang saat ini masih 
dalam uji klinis tidak dapat menyebabkan hasil positif pada tes virus, saat melihat apakah seseorang sedang terinfeksi. Jika tubuh berhasil menciptakan respon imun spesifik terhadap virus corona, ada kemungkinan akan mendapatkan hasil positif pada beberapa tes antibodi. Tes antibodi menunjukkan seseorang pernah mengalami infeksi sebelumnya dan tubuh memiliki tingkat perlindungan tertentu terhadap virus. Hanya saja, para ahli masih memantau bagaimana vaksinasi COVID-19 bisa memengaruhi hasil pengujian antibodi.

3. Orang yang Sudah Tertular dan Sembuh dari COVID-19 Perlu Divaksinasi

Ini karena risiko kesehatan yang para terkait COVID-19 dan fakta bahwa infeksi ulang COVID-19 sangat mungkin terjadi. Vaksin harus diberikan pada seseorang yang pernah terinfeksi COVID19. Saat ini, para ahli belum mengetahui sampai kapan seseorang terlindungi dari sakit lagi setelah sembuh dari COVID-19. Kekebalan tubuh yang didapatkan seseorang dari infeksi (kekebalan alami), bervariasi pada setiap orang.

Beberapa bukti awal menunjukkan kekebalan alami mungkin tidak bertahan lama. Namun, hal ini masih dipelajari lebih lanjut. Sementara ini, prioritas vaksin akan difokuskan pada mereka yang belum tertular terlebih dulu.

4. Vaksin Melindungi Tubuh dari Infeksi COVID-19

Vaksinasi COVID-19 bekerja dengan membentuk sistem kekebalan tubuh tentang bagaimana mengenali dan melawan virus yang menyebabkan COVID-19, dan melindungi tubuh dari infeksi COVID-19.

5. Vaksin COVID-19 Tidak Akan Mengubah DNA Seseorang

Vaksin COVID-19 tidak mengubah atau berinteraksi dengan DNA dengan cara apapun. Vaksin RNA Messenger atau vaksin mRNA adalah vaksin COVID-19 pertama yang diizinkan untuk digunakan di Amerika Serikat. Vaksin ini mengandung sebagian protein dalam virus yang memicu respon imun dalam tubuh. Perlu diketahui, mRNA dari vaksin COVID-19 tidak pernah memasuki inti sel, tempat DNA disimpan. Artinya, mRNA tidak bisa mempengaruhi atau berinteraksi dengan DNA dengan cara apa pun.

Vaksin yang digunakan di Indonesia saat ini yaitu Sinovac. Vaksin Covid-19 Sinovac adalah vaksin asal China berjenis virus mati yang kini sudah didatangakan Indonesia sebanyak 1,2 juta vaksin. Vaksin Covid-19 Sinovac dari China yang tergolong vaksin virus mati, sudah mendapat izin penggunaan darurat atau emergency use authorization (EUA) vaksin virus corona (Covid-19) dari Badan Pengawas Obat dan Makanan (BPOM).

Vaksin Sinovac adalah vaksin berjenis inactivated vaccine atau virus mati. Secara singkat inactivated vaccine adalah vaksin menggunakan versi lemah atau inaktivasi dari virus untuk memancing respons imun. Vaksin inactivated memerlukan beberapa dosis dari waktu ke waktu untuk mendapatkan imunitas berkelanjutan terhadap penyakit.

Vaksin inactivated telah digunakan untuk penyakit Hepatitis A, Flu, Polio, dan Rabies. Bio Farma bekerja sama dengan Sinovac agar bisa memproduksi vaksin yang bernama CoronaVac. Oleh karena itu, uji klinis fase III dilakukan di Indonesia. Untuk pengujian klinis di Indonesia, Bio Farma bekerjasama dengan Fakultas Kedokteran Universitas Padjadjaran untuk menyiapkan uji klinis vaksin Covid-19.

\section{PENUTUP \\ Kesimpulan}

Vaksinasi adalah proses pemberian vaksin melalui disuntikkan maupun diteteskan ke dalam mulut untuk meningkatkan produksi antibodi guna menangkal penyakit tertentu.

Kegiatan edukasi tentang pentingnya vaksinasi di Masjid Al-Ikhlas hampir semua peserta antusias dan merasakan manfaatnya. Pelaksanaan pengabdian untuk jamaah Masjid Al-Ikhlas Cengkareng, Jakarta Barat ini dapat disimpulkan berhasil sampai tahap diskusi dengan menjawab kekhawatiran tentang keamanan dan efek samping dari vaksin COVID-19. Keberhasilan ini ditunjukkan antara lain oleh: 
1. Adanya kesesuain materi dengan kekhawatiran Jamaah masjid Al-Ikhlas tentang keamanan dan efek samping dari vaksin COVID-19.

2. Adanya respon positif dari jamaah masjid Al-Ikhlas yang ditunjukkan dengan berbagai pertanyaan yang mereka sampaikan.

3. Jamaah masjid Al-Ikhlas telah memahami pentingnya vaksinasi di masa pandemi saat ini serta mengetahui manfaat dan efek samping dari vaksin COVID-19.

\section{Saran}

Saran yang diberikan dari kegiatan pengabdian kepada masyarakat yang dilakukan oleh tim pengabdian masyarakat Mahasiswa Manajemen, Fakultas Ekonomi, Universitas Pamulang kepada jamaah masjid Al-Ikhlas adalah sebagai berikut:

a. Bagi jamaah masjid Al-Ikhlas Cengkareng, Jakarta Barat agar tidak perlu khawatir lagi tentang keamanan dan efek samping dari vaksin COVID-19.

b. Pelatihan serupa dapat dilaksanakan kembali dengan peserta (audience) yang lebih banyak/luas, dan dengan topik lainnya.

\section{DAFTAR PUSTAKA}

Affandi, A., Sarwani, A. S., Erlangga, H., Siagian, A. O., Purwanto, A., Effendy, A. A., ... \& Wahyitno, C. D. M. (2020). Optimization of MSMEs Empowerment in Facing Competition in the Global Market during the COVID-19 Pandemic Time. Systematic Reviews in Pharmacy, 11(11), 1506-1515.

Haque, M. G., Munawaroh, M., \& Sunarsi, D. (2020). Analysis of SMEs Culinary Marketing Strategy During Covid 19 Pancemic: A Study at "Sate Bebek Cilegon" Resto in Cilegon, Banten. International Journal of Education, Information Technology, and Others, $3(2), 447-451$.

Nurjaya, N., Sunarsi, D., Effendy, A. A., Teriyan, A., \& Gunartin, G. (2021). Pengaruh Etos Kerja Dan Disiplin Kerja Terhadap Kinerja Pegawai Pada Dinas Kehutanan Dan Perkebunan Kota Bogor. JENIUS (Jurnal Ilmiah Manajemen Sumber Daya Manusia), $4(2), 172-184$.

Yuangga, K. D., \& Sunarsi, D. (2020). Pengembangan media dan strategi pembelajaran untuk mengatasi permasalahan pembelajaran jarak jauh di pandemi covid-19. JGK (Jurnal Guru Kita), 4(3), 51-58. 